\title{
Ileal proteomic changes associated with IL-25-mediated resistance against intestinal trematode infections
}

\author{
María Álvarez-Izquierdo, J. Guillermo Esteban, Carla Muñoz-Antoli and Rafael Toledo*
}

\begin{abstract}
Background: Echinostoma caproni (Trematoda: Echinostomatidae) is an intestinal trematode, which has been extensively used to investigate the factors that determine the rejection of intestinal helminths. In this sense, several studies have shown that IL-25 is critical for the development of resistance against E. caproni in mice. In fact, treatment of mice with recombinant IL-25 generates resistance against primary E. caproni infection. However, the mechanisms by which IL-25 induces resistance remain unknown.
\end{abstract}

Methods: To study the mechanisms responsible for resistance elicited by IL-25, we analyzed the ileal proteomic changes induced by IL-25 in mice and their potential role in resistance. To this purpose, we compared the protein expression profiles in the ileum of four experimental groups of mice: naïve controls; E. caproni-infected mice; rlL-25treated mice; and rlL-25-treated mice exposed to E. caproni metacercariae.

Results: Quantitative comparison by 2D-DIGE showed significant changes in a total of 41 spots. Of these, 40 validated protein spots were identified by mass spectrometry corresponding to 24 proteins.

Conclusions: Our results indicate that resistance to infection is associated with the maintenance of the intestinal epithelial homeostasis and the regulation of proliferation and cell death. These results provide new insights into the proteins involved in the regulation of tissue homeostasis after intestinal infection and its transcendence in resistance.

Keywords: Proteomics, Intestine, Interleukin-25, Intestinal helminths, Trematoda, Echinostoma caproni

\section{Background}

Intestinal helminth infections affect more than one billion people worldwide, mainly in developing regions of Asia, Africa and Latin America [1]. These infections cause high morbidity, with most common symptoms related to effects on nutrition inducing malabsorption syndrome, vitamin deficiencies, growth retardation or impaired cognitive function among other disorders. Moreover, other complications such as intestinal obstruction, chronic dysentery, rectal prolapse, anemia or

*Correspondence: rafael.toledo@uv.es

Área de Parasitología, Departamento de Farmacia y Tecnología Farmacéutica y Parasitología, Facultad de Farmacia, Universitat de

València, Avda. Vicent Andrés Estellés s/n, 46100 Burjassot, Valencia, Spain debilitating disease may appear [2,3]. Apart from their importance for human health, helminth infections are a relevant cause of economic losses in livestock, both by decreased productivity, an also in relation to the indirect costs of anthelmintic treatments [4]. Intestinal helminth infections caused by trematodes constitute a major group affecting both humans and animals [5]. Intestinal trematodes are a large group of parasites and about seven million people are infected worldwide [6]. About 76 species belonging to the family Echinostomatidae have been reported to infect humans [6]. Human infection occurs as a consequence of eating raw or undercooked foods containing infective metacercariae. High incidence of intestinal trematodiasis is strongly associated with populations living near freshwater bodies and the practice of 
eating raw or undercooked aquatic products [5]. One of the most relevant group of trematodes causing human infections, mainly in East and Southeast Asia, are the members of the family Echinostomatidae. Echinostomes are cosmopolitan parasites that infect a large number of different warm-blooded hosts. More than 20 species of Echinostoma are known to cause human infections worldwide [5]. Moreover, members of the genus Echinostoma, and particularly Echinostoma caproni, have been widely used as experimental models to study helminthvertebrate host relationships, especially in relation to the factors that determine the resistance to intestinal helminth infections. Echinostoma caproni is an intestinal trematode without tissue migration within the definitive host. The metacercariae excyst in the duodenum and the excysted worms migrate to the ileum and attach to the mucosa [7]. Echinostoma caproni has a wide range of definitive hosts, although its compatibility differs considerably between rodent species due to different worm survival and development in each host species [7]. In mice, the infection becomes chronic, while in hosts of low compatibility, such as rats, the worms are rapidly rejected in a few weeks post-infection (wpi) $[8,9]$.

In recent years, IL-25 is considered a crucial cytokine in resistance to intestinal helminths. IL-25 induces Th2 immunity and facilitates anti-inflammatory functions via the downregulation of Th17 and Th1 responses [10-12]. Expression of IL-25 induces resistance to gastrointestinal helminth infections due to the activation of Th2 responses that mediate effector mechanisms (including mast cell hyperplasia, smooth muscle hypercontractility, expression of RELM- $\beta$, and intestinal mastocytosis, among others) for parasite expulsion [13]. Intestinal tuft cells are the main source of IL-25 and release IL-25 upon helminth establishment. Subsequently, group 2 of innate lymphoid cells (ILC2) produce large amounts of IL-13 activating dendritic cells in the lamina propria and enhancing their migration to mesenteric lymph nodes to polarize naïve CD4+ T cells into Th2. ILC2 and basophils can also perform antigen presentation to CD4+ T cells and induce Th2 polarization. Th2-polarized cells release an array of cytokines and expand themselves through positive feedback loops, amplifying the response and enhancing resistance to infection [13].

Previous studies of our group showed that IL-25 is crucial for resistance to E. caproni and the susceptibility of mice relies on the inability of this host species to produce IL-25 in response to infection $[14,15]$. Susceptibility of mice to primary E. caproni infection was associated with low expression of intestinal IL-25, whilst deworming via administration of praziquantel (pzq) was accompanied by an increase in IL-25 production and, subsequently, the development of a Th2-type phenotype preventing the establishment of secondary infections $[14,15]$. However, little is known about the mechanism by which IL-25 generates resistance against intestinal helminths. In the present study, we analyzed the changes in the production of proteins induced by IL-25 in the ileum of mice that may be implicated in the generation of resistance against intestinal helminths.

\section{Methods}

\section{Animal and infection procedures}

The present study was achieved using a total of 15 male ICR (CD1) mice weighing 30-35 g. The E. caproni strain and the infection procedures carried out have been previously described $[9,16]$. Briefly, encysted metacercariae were removed from kidneys and pericardium of experimentally infected Biomphalaria glabrata snails and used for infection. Mice were randomly allocated into 4 groups (3 mice in each group). Animals belonging to one of the groups were infected by gastric gavage with 50 metacercariae of E. caproni. Mice of the second group were treated with rIL-25 (R\&D Systems ${ }^{\circledR}$, Minneapolis, USA) (concentration: $0.2 \mu \mathrm{g} / \mu \mathrm{l}$ each) in $150 \mu \mathrm{l}$ of PBS during each of the 4 days prior to infection with 50 metacercariae of E. caproni as described above. Mice of the third group were simply treated with penicillin under the conditions described above. This group was not exposed to metacercariae of E. caproni. Finally, the remaining 5 mice were used as a control and were not exposed to rIL-25 or E. caproni metacercariae. All mice were necropsied one week after the experimental infection of the animals belonging to the first and second groups of mice. The animals were maintained under standard conditions with food and water ad libitum.

\section{Intestinal epithelial cell isolation and protein extraction}

Ileal sections from mice in each group were removed at necropsy and intestinal epithelial cells (IECs) were isolated. Briefly, the intestinal sections were opened longitudinally and rinsed by shaking in washing buffer: ice-cold Hank's balanced salt solution (HBSS) containing 2\% heatinactivated fetal calf serum (FCS). Supernatant was then removed, and fresh washing buffer was added to the ileal sections. This procedure was repeated 4 times, until the supernatant was clear. The tissue was cut into small, 1 $\mathrm{cm}$ long, segments and incubated for $20 \mathrm{~min}$ at $37^{\circ} \mathrm{C}$ in HBSS containing 10\% FCS, 1 nM EDTA, 1 mM DTT, 100 $\mathrm{U} / \mathrm{ml}$ penicillin and $100 \mu \mathrm{g} / \mathrm{ml}$ streptomycin (dissociation buffer). The supernatant was collected and maintained on ice and the incubation was repeated a second time with fresh dissociation buffer. Supernatants were combined and filtered through a $100 \mathrm{~nm}$ cell strainer before IECs were pelleted by centrifuging at $200 \times g$ for $10 \mathrm{~min}$ 
at $4{ }^{\circ} \mathrm{C}$ and washed three times in PBS under the same centrifuge conditions to remove any residual medium.

Protein extraction was performed using M-PER Mammalian Protein Extraction Reagent (Thermo Fisher Scientific, Waltham, USA) according to the manufacturer's instructions. Extraction reagent was added to the IECs pellet $(20: 1, v / v)$, vortexed to mix and incubated at room temperature (RT) for $20 \mathrm{~min}$ under continuous gentle agitation. The lysate was then clarified by centrifugation at $18,000 \times g$ for $15 \mathrm{~min}$ at $4{ }^{\circ} \mathrm{C}$, transferred into a new tube, and stored at $-80^{\circ} \mathrm{C}$ until use.

\section{Preparation of biological replicates and protein labeling}

To increase the biological significance avoiding erroneous conclusions related to individual variations, 4 biological replicates were prepared for each experimental group: infected with E. caproni; rIL-25-treated mice exposed to E. caproni metacercariae; rIL-25-treated mice; and naïve animals.

Three of these replicates were obtained from different animals and the fourth was obtained by mixing the previous three by applying the same amount of protein from each sample $(20 \mu \mathrm{g} / \mathrm{sample})$ and included to increase the power of the analysis [17]. Then, $200 \mu \mathrm{g}$ of protein from each biological replicate was cleaned and precipitated using 2-D Clean-Up kit (GE Healthcare, Chicago, USA) to remove salts and other substances that interfere with labeling and electrophoresis. The samples were resuspended in DIGE tagged buffer (7 M urea, $2 \mathrm{M}$ tiourea, 4 $\%$ CHAPS and $20 \mathrm{mM}$ Tris). The protein concentration after precipitation was determined using the RC DC (BioRad Protein Assay; Bio-Rad, Hercules, USA) method, using BSA as standard protein. The concentrations for labeling with fluorochromes should be between 1-20 $\mu \mathrm{g}$ / $\mu \mathrm{l}$, with optimum concentration for labeling according to the manufacturer's instructions being between 5-10 $\mu \mathrm{g} /$ $\mu \mathrm{l}$. With the precipitated samples, $100 \mu \mathrm{g}$ pools needed for the experiment were made for each group, with equimolar amounts of each sample in each group and quantified again. The DIGE experiment was designed to perform 8 gels containing the samples of the four groups to be compared. After checking that the $\mathrm{pH}$ of all samples was between 8-8.5, CyDye DIGE Fluor (GE Healthcare ${ }^{\circledR}$ ) fluorochromes were labeled according to the protocol recommended by the manufacturer. One microliter of dye $(400 \mathrm{pmol})$ was added to each sample and maintained on ice for $30 \mathrm{~min}$ in the dark. The reaction was stopped by adding $1 \mu \mathrm{l}$ of $10 \mathrm{mM}$ lysine. To minimize any dyespecific labeling artefacts, 2 biological replicates of each experimental group were labeled with $\mathrm{Cy} 3$ and the other 2 were labeled with Cy5. The internal standard, prepared by mixing the same amount of protein of each sample included in the experiment, was always labeled with Cy2.

\section{D differential in gel electrophoresis (2D-DIGE)}

To analyze the effect of IL-25 in the course of E. caproni infection, ileal protein extracts from naïve, infected, rIL25-treated and rIL-25-treated and exposed to metacercariae mice were compared over 8 2D-DIGE to analyse changes in the intestinal production of proteins. The 8 pairs of Cy3- and Cy5-labeled biological replicates (50 $\mu \mathrm{g}$ of protein each) were combined with a $50 \mu \mathrm{g}$ aliquot of the Cy2-labeled internal standard. The mixtures containing $150 \mu \mathrm{g}$ of protein were then separated in the first dimension, i.e. isoelectric focusing, and the second dimension, i.e. molecular weight. The IPG strips $(24 \mathrm{~cm}$, non-linear $\mathrm{pH} 3-11$ ) were rehydrated overnight with rehydration buffer (8 M urea, $4 \%$ CHAPS, $1 \%$ ampholytes and $12 \mu \mathrm{l} / \mathrm{ml}$ of DeStreak ${ }^{\mathrm{TM}}$ (Merck, St. Louis, USA), and the labeled samples were then applied to the strips by anodic cup loading, after the addition of DTT and ampholytes up to a final concentration of $65 \mathrm{mM}$ and $1 \%$, respectively. Isoelectric focusing was carried out at $20{ }^{\circ} \mathrm{C}$ in the Ettan IPGphor 3 System (GE Healthcare) as follows: (i) $300 \mathrm{~V}$ for $4 \mathrm{~h}$; (ii) gradient to $1000 \mathrm{~V}$ for $6 \mathrm{~h}$; (iii) gradient to $8000 \mathrm{~V}$ for $3 \mathrm{~h}$; and (iv) $8000 \mathrm{~V}$ up to $32,000 \mathrm{Vh}$. Prior to the second dimension the strips were equilibrated in two steps, $15 \mathrm{~min}$ each, in equilibration buffer (50 mM Tris, $6 \mathrm{M}$ urea, 30\% glycerol and $2 \%$ SDS) containing either $2 \%$ DTT or $2.5 \%$ iodoacetamide, respectively. The separation of proteins in the second dimension was performed on an Ettan DALTsix system (GE Healthcare) using $12.5 \%$ polyacrylamide gels. Electrophoresis was run at $1 \mathrm{~W} /$ gel for $1 \mathrm{~h}$ followed by $5 \mathrm{~h}$, approximately, at $15 \mathrm{~W} /$ gel.

\section{Imaging and 2D-DIGE analysis}

Gels were scanned in a Typhoon ${ }^{\mathrm{TM}} 9400$ Variable Mode Imager (GE Healthcare) at appropriate wavelengths for each fluorophore at $50 \mu \mathrm{m}$ resolution: Cy2 (488/520 nm); Cy3 (532/580 nm); and Cy5 (633/670 nm). The irrelevant information was removed using ImageQuant Tools software and DeCyder v7.0 software (Applied Biomics Inc., Hayward, USA) was used for image analysis. The differential in gel analysis module was employed for automatic spot detection and abundance measurements in each individual gel, comparing the normalized volume ratio of each spot from a Cy3- or Cy5-labeled sample to the corresponding Cy 2 signal from the internal standard. Datasets were collectively analyzed by means of the biological variation analysis module of the same software, allowing inter-gel matching and calculation of standardized average volume ratios (AVRs) for each protein spot over all the gels that comprised the study. Statistical analysis was carried out for each alteration in AVR using one-away ANOVA, together with the corresponding post-hoc analysis (Bonferroni's post-hoc t-test), and the false discovery 
rate (FDR) test, which avoids the introduction of false positives when performing multiple comparisons. FDR test determines adjusted $P$-values for each test and controls the number of false discoveries in those tests that result in a discovery. Statistical significance was considered when $P<0.01$ and $q<0.05$ in the ANOVA and FDR analyses, respectively. Moreover, inter-gel matching of statistically different spots was manually confirmed.

Unsupervised principal components analyses (PCA) and hierarchical cluster analyses (HCA) (based on Euclidean distance) were performed using the DeCyder extended data analysis module, both on all protein spots present at least in 7 of the 8 gels of the experiment (85\% presence) and the set of spots that were found to be significantly differentially expressed among the groups compared. These multivariate analyses clustered the individual biological replicates based on a collective comparison of expression patterns from the set of proteins chosen, without any a priori knowledge of the biological reasons for clustering [17-20].

\section{LC-MS/MS and protein identification}

Spots showing significant changes in protein abundance among groups were manually excised from the gel and washed twice with double-distilled water. Thereafter, proteins were reduced in $100 \mathrm{mM}$ ammonium bicarbonate containing $10 \mathrm{mM}$ DTT for $30 \mathrm{~min}$ at $56{ }^{\circ} \mathrm{C}$, alkylated with iodoacetamide $55 \mathrm{mM}$ in $100 \mathrm{mM}$ ammonium bicarbonate for $20 \mathrm{~min}$ at RT in the dark and, finally, digested in-gel with an excess of sequencing grade trypsin (Promega, Madison, USA) overnight at $37{ }^{\circ} \mathrm{C}$, as described before [21]. Protein digestion was stopped with $1 \%$ trifluoroacetic acid (TFA) and peptides were dried in a vacuum centrifuge and resuspended in $7 \mu \mathrm{l}$ of $0.1 \%$ TFA, pH 2. Following, liquid chromatography and tandem mass spectrometry (LC-MS/MS) was performed for protein identification. Five microliters of each sample was loaded onto a trap column: NanoLC Column, 3 $\mu \mathrm{C} 18-\mathrm{CL}, 350 \mu \mathrm{m} \times 0.5 \mathrm{~mm}$ (Eksigent, AB Sciex, Old Connecticut Path, USA) and desalted with $0.1 \%$ TFA at $3 \mu \mathrm{l} / \mathrm{min}$ for $5 \mathrm{~min}$. The peptides were then loaded onto an analytical column: LC Column, $3 \mu$ C18-CL, $75 \mu \mathrm{m}$ $\times 12 \mathrm{~cm}$ (Nikkyo Technos, Tokyo, Japan), equilibrated with $5 \%$ acetonitrile (ACN) and $0.1 \%$ formic acid (FA). Elution was carried out with a gradient of $5-40 \%$ B in A for $15 \mathrm{~min}$ (A: 0.1\% FA; B: ACN, 0.1\% FA) at a constant flow rate of $300 \mathrm{nl} / \mathrm{min}$. Peptides were analyzed in a mass spectrometer nanoESI qQTOF (5600 TripleTOF; AB Sciex, Old Connecticut Path, USA).

The sample was ionized applying $2.8 \mathrm{kV}$ to the spray emitter. Analysis was carried out in a data-dependent mode. Survey MS1 scans were acquired from 350-1250 $\mathrm{m} / \mathrm{z}$ for $250 \mathrm{~ms}$. The quadrupole resolution was set to
'UNIT' for MS2 experiments, which were acquired 100$1500 \mathrm{~m} / \mathrm{z}$ for $50 \mathrm{~ms}$ in the 'high sensitivity' mode. The following switch criteria were used: charge, $2+$ to $5+$; minimum intensity; 70 counts per second (cps). Up to 50 ions were selected for fragmentation after each survey scan. Dynamic exclusion was set to $15 \mathrm{~s}$. The system sensitivity was controlled with 2 fmol of 6 proteins (LC Packings, Thermo Fisher Scientific, San Diego, USA).

\section{Database search}

Database search was carried out using the ProteinPilot v5.0. search engine (AB Sciex). ProteinPilot default parameters were employed to generate a peak list directly from 5600 TripleTof wiff files and the Paragon algorithm of ProteinPilot v5.0 was used to search in Uniprot database (version 01-2017; https://www.uniprot.org) with the following parameters: trypsin specificity; cys-alkylation; taxonomy restricted to mice; and the search effort set to through. Identifications were considered positive when there were at least two different matching peptides $(\geq$ 95\% confidence) and the ProteinPilot unused score was $>1.3$, which means that proteins are identified with confidence $\geq 95 \%$. Functional annotation was performed using the Uniprot database.

\section{Results \\ Experimental infection with metacercariae of E. caproni and worm recovery}

All the rIL-25-treated mice exposed to metacercariae were negative to infection at necropsy. In contrast, all the non-treated mice exposed to metacercariae became positive to infection and the percentage of worms recovered ranged between $40-100 \%$ (mean $69.36 \pm 16.29 \%$ ).

\section{Analysis of protein production profiles by 2D-DIGE}

The 2D-DIGE proteomic analysis was implemented on whole ileal cell extracts in a total of 12 replicates, corresponding to 4 experimental groups (3 replicates each) referred as: control, rIL-25-treated mice; rIL-25treated mice exposed to metacercariae; and infected mice. 2D-images were analyzed using the DeCyder software and both multivariate and univariate analysis were applied to identify: (i) the similarity in intestinal protein production profiles among experimental groups; and (ii) particular differences in protein abundance between each group with respect to the others (Additional file 1: Figure S1, Additional file 2: Figure S2, Additional file 3: Figure S3).

The inter-gel spot matching revealed 172 well defined spots with $85 \%$ of presence, found in at least 7 of the 8 gels that covered the experiment. The average abundance of each spot among the 24 images of our study was calculated, and significant differences were considered when 
$P<0.01$, both in one-way ANOVA and in the post-hoc analyses.

\section{Multivariate statistics: principal component and cluster analysis}

PCA and CAs between groups were performed on the 172 spots with $85 \%$ of presence in the experiment and the 41 validated spots displaying significant differences among groups, with $P<0.01$ in one-way ANOVA. In the three cases, both PCA and CAs were compared two by two: (i) including biological replicates from control and rIL25-treated mice; (ii) including biological replicates from rIL25-treated mice and rIL25-treated mice exposed to metacercariae; and (iii) including biological replicates from infected and rIL25-treated mice exposed to metacercariae. In the PCA, data clustered according the group mice, spots with greater presence in each group of mice with respect to the other appeared highlighted. Likewise, CAs grouped the spots according to how similar their expression profile was between compared experimental groups. Hence, following the results of the multivariate statistical analyses, the 4 experimental groups were used as 3 comparative pairs due to their importance to analyze the role of IL-25: (i) infected animals vs rIL-25-treated animals; (ii) rIL-25-treated mice exposed to metacercariae $v s$ rIL-25-treated animals; and (iii) naïve controls $v s$ rIL-25-treated mice (Figs. 1, 2, 3).

\section{One-way ANOVA and post-hoc analysis}

A total of 59 differentially expressed spots (34.3\%) were found displaying $q<0.05$ in the FDR test. To guarantee the accurate comparison of spots among gels, the correspondence of these 59 spots were manually validated through all the gels, and 41 were unequivocally confirmed (Fig. 4, Additional file 1: Figure S1, Additional file 2: Figure S2, Additional file 3: Figure S3).

Differentially identified spots were up- or downregulated (5 and 24, respectively) in the ileum of rIL-25treated mice with respect $\mathrm{rIL}-25$-treated animals and infected mice ( 4 and 1 , respectively). Moreover, we found 7 spots differentially identified between naïve controls and rIL-25-treated mice from which 2 of them were upregulated and the remainder 5 spots were downregulated. Further details of the computational comparison of differential spots are shown in Additional file 4: Table S1 for non-similar groups (i.e. naïve controls vs rIL-25treated animals exposed to metacercariae and rIL-25treated mice $v s$ infected animals).

\section{Identification of differentially produced proteins}

We accurately identified by MS and database search a total of 40 validated spots (5 upregulated and 24 downregulated in rIL-25-treated animals exposed to metacercariae $v s$ rIL-25-treated mice; 4 upregulated and 1 downregulated in rIL-25-treated animals exposed to metacercariae $v s$ infected mice; 2 upregulated and 5 downregulated in rIL-25-treated mice $v s$ naïve animals) (Fig. 4). They correspond to a total of 24 different proteins, since 6 of these proteins were identified in more than 1 protein spot. These redundancies appear to be related to different post-translational modifications, different isoforms (differentiated on the basis of molecular weight or isoelectric point) or to protein modifications during the preparation of the samples. Identified proteins are classified in Tables 1, 2, 3 according to their function, indicating for each spot the up- or downregulation in relation to inoculation of rIL25 in presence and/ or absence of $E$. caproni infection in mice. Differentially expressed proteins were classified in: metabolic enzymes; structural proteins; antioxidant and detoxifying enzymes; calcium-binding proteins; and cell regulation proteins.

\section{Discussion}

Recent studies of our group have shown that IL-25 is crucial in resistance against $E$. caproni secondary infections. Susceptibility to primary infections was associated with low levels of intestinal IL-25 expression, whilst deworming by treatment with praziquantel induced a sudden increase in IL-25 expression preventing the establishment of secondary infections $[14,15]$. However, the role of IL-25 in resistance to infection is not well defined. Herein, we analyze the proteomic changes induced by IL-25 that may contribute to resistance to infection.

Resistance to E. caproni infection has been associated with the preservation of the intestinal homeostasis despite the possible damage induced by the parasite. In resistant hosts, E. caproni infection elicits a rapid renewal of the intestinal epithelium to maintain the intestinal homeostasis, impairing the proper worm establishment. In contrast, in susceptible hosts, such as mice, the establishment of chronic infections is related to the disruption of the intestinal homeostasis causing tissue hyperplasia $[17,19,20]$. Although mice are susceptible hosts, treatment with rIL-25 prior to infection induces complete resistance to the infection [15]. Our results support that IL-25 may contribute to resistance by the enhancement of intestinal homeostasis via activation of the canonical wingless-related integrator site (Wnt)/ $\beta$-catenin signaling pathway. Treatment of naïve mice with rIL-25 only elicited changes in the production of a total of five proteins, including the structural protein junction plakoglobin or $\beta$-catenin. This protein is a member of the catenin family, paralog of $\beta$-catenin, and is a component of desmosomes. It is involved in the mechanisms of cell adhesion and is essential to maintain and regulate intestinal epithelial homeostasis [22-24]. Plakoglobin 


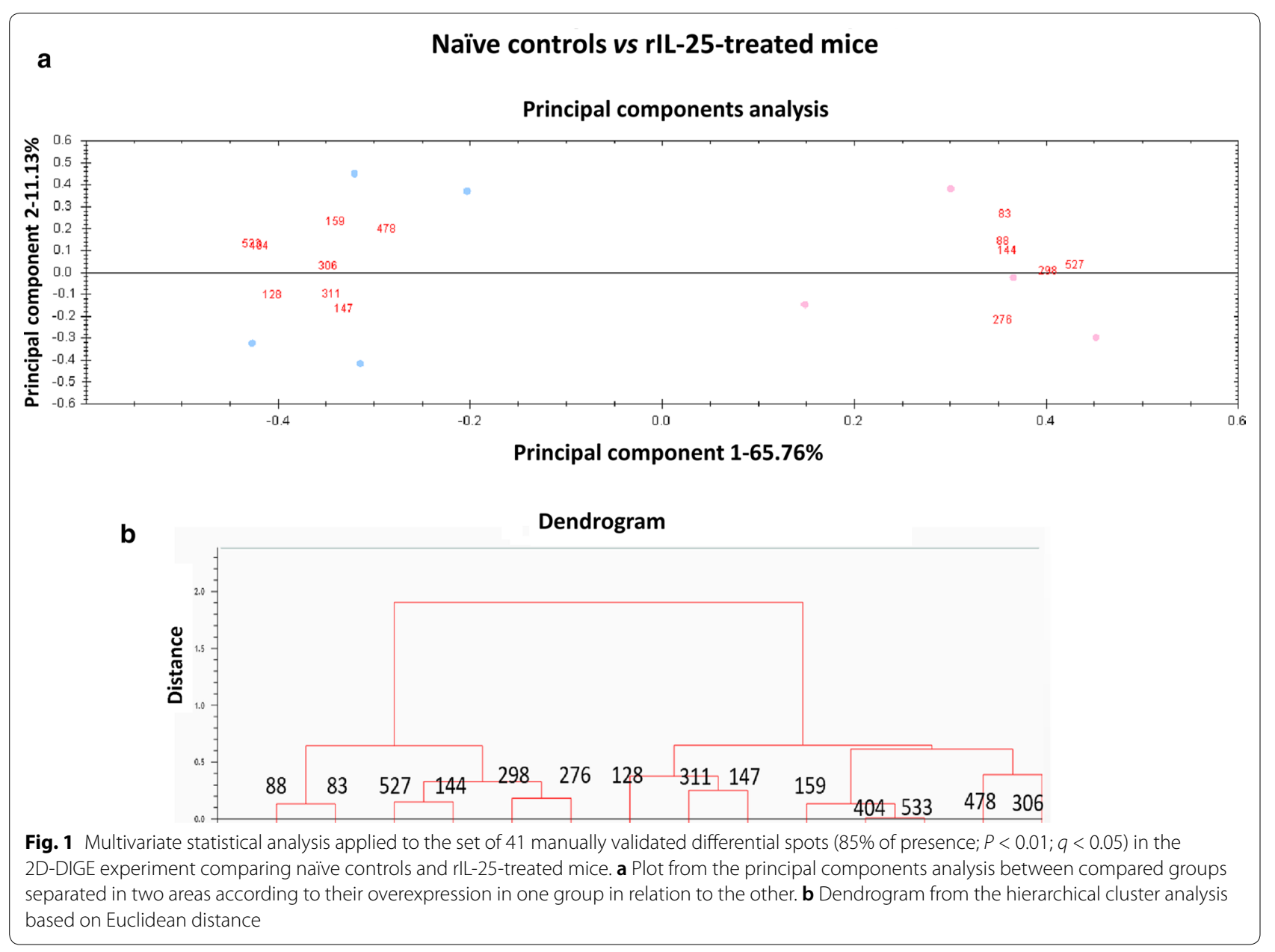

participates in the canonical pathway of Wnt/ $\beta$-catenin. Elevated levels of plakoglin promote the stabilization and nuclear localization of $\beta$-catenin enhancing the activation of Wnt/ $\beta$-catenin signaling, and activation of this pathway is essential for the maintenance of intestinal homeostasis $[25,26]$. Wnt signaling activation is dependent on the nuclear translocation of $\beta$-catenin. The intracellular accumulation of non-phosphorylated $\beta$-catenin induces its translocation to the nucleus and the consequent activation of the T-cell factor/lymphocyte enhancer factor transcription factor families to regulate gene transcription [27]. Plakoglobin participates in the canonical pathway of $\mathrm{Wnt} / \beta$-catenin signaling since this protein inhibits the glycogen synthase kinase (GSK3 $\beta$ )-mediated nuclear localization of $\beta$-catenin. GSK-3 $\beta$ is a relevant member since it regulates the $\mathrm{Wnt} / \beta$-catenin target gene expression by controlling the level of cytoplasmic $\beta$-catenin and its nuclear traslocation [28]. Elevated levels of plakoglin facilitate the stabilization and nuclear localization of $\beta$-catenin [25] and may enhance intestinal homeostasis despite the damage caused by the infection. Oudhoff et al. [29] reported that $\mathrm{Wnt} / \mathrm{\beta}$-catenin signaling is an important component of resistance to the intestinal nematode Trichuris muris in mice. These authors showed that Wnt expression programs are induced upon infection with T. muris eggs and wild type mice were able to expel the infection. In contrast, mice deficient in SETD7 (a member of the suppressor of variegation 3-9-Enhancer of zeste-Trithorax domain-containing family of lysine methyltransferases) were not able to reject the infection. SETD7 controls IEC turn over by the modulation of the developmental signaling pathway $\mathrm{Wnt} / \beta$-catenin. Lack of SETD7 resulted in downregulation of Wnt/ $\beta$-catenin and susceptibility to infection [29]. The fact that exposure of rIL-25-treated mice to E. caproni metacercariae induced a significant downregulation of three isoforms of plakoglobin with respect to rIL-25-treated mice supports that plakoglobin plays a major role in E. caproni infections, and its potential role in resistance to infection.

Strikingly, two other proteins involved in cell differentiation and tissue homeostasis also became altered by the treatment with rIL-25. Proliferation-associated 2G4 
Infected vs rIL-25-treated mice exposed to metacercariae

a

Principal components analysis

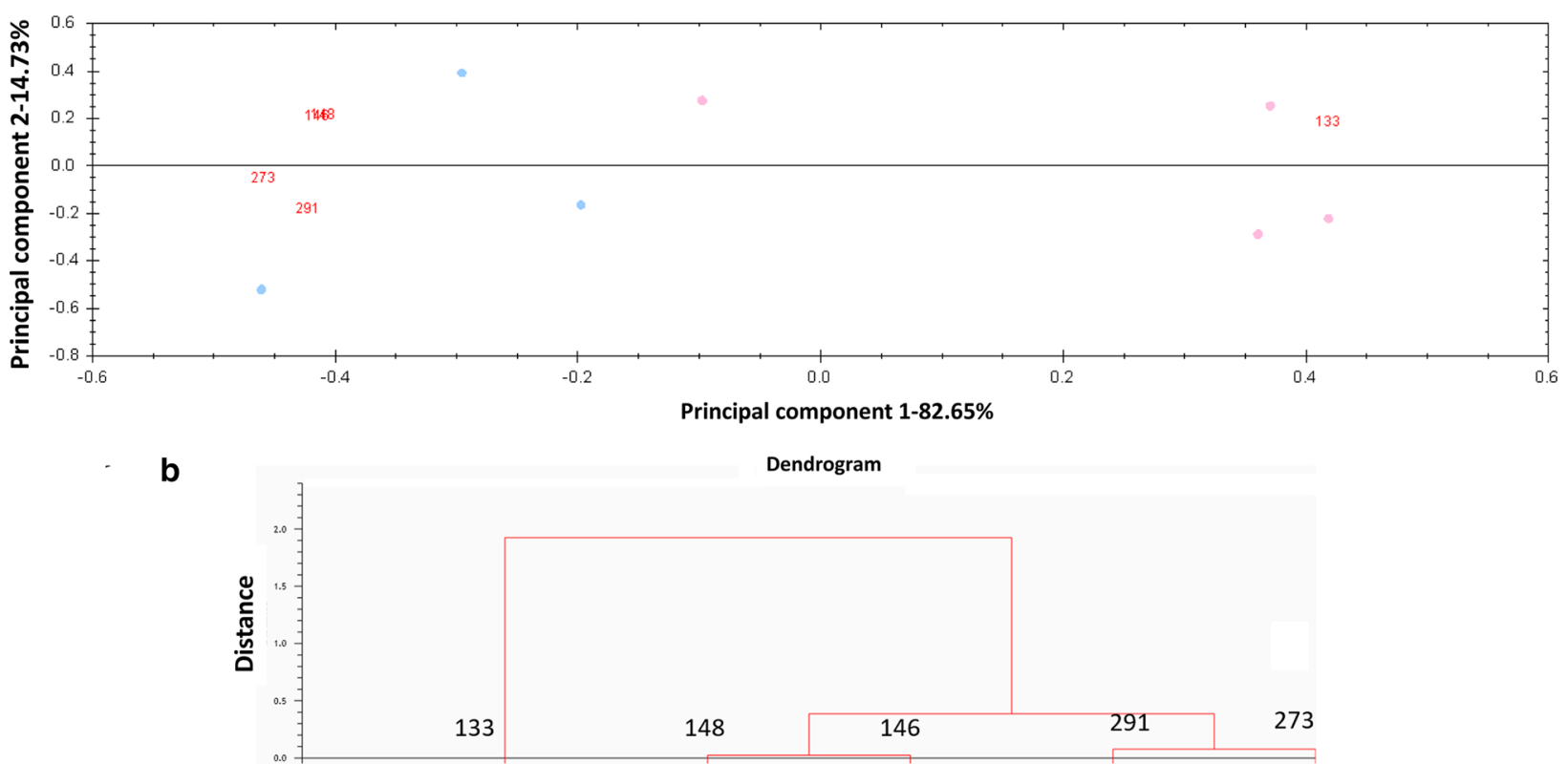

Fig. 2 Multivariate statistical analysis applied to the set of 41 manually validated differential spots (85\% of presence; $P<0.01 ; q<0.05)$ in the 2D-DIGE experiment comparing infected vs rIL-25-treated mice exposed to Echinostoma caproni metacercariae. a Plot from the principal components analysis between compared groups separated in two areas according to their overexpression in one group in relation to the other. $\mathbf{b}$ Dendrogram from the hierarchical cluster analysis based on Euclidean distance)

(PA2G4) and a receptor of activated protein $C$ kinase 1 (RACK1) were found to be downregulated in rIL-25treated mice with respect to naïve mice. PA2G4, also known as EBP1, is an RNA-binding protein implicated in growth regulation. This protein participates in preribosomal ribonucleoprotein complexes and is involved in ribosome assembly and the regulation of intermediate and late steps of rRNA processing. EBP1 interacts with the cytoplasmic domain of the ErbB3 receptor contributing to the transduction of growth regulatory signals. This protein also acts as a transcriptional corepressor of androgen receptor-regulated genes and other cell cycle regulatory genes via its interactions with histone deacetylases. Furthermore, EBP1 is involved in growth inhibition [30, 31]. The EBP1-binding in promoters regulated by E2F can result in an improved ability of EBP1 to suppress gene transcription regulated by the cell cycle and prevent cell growth [30, 32]. Furthermore, the expression of EBP1 generates the negative expression of the androgen receptor (AR) and a number of its target genes, thereby inhibiting AR-regulated cell growth [30-33]. RACK1 is a member of the tryptophan-aspartate repeat (WD-repeat) family of proteins. This protein shows significant homology to the $\beta$ subunit of G-proteins (Gß). RACK1 facilitates protein binding by adopting a seven-bladed $\beta$-propeller structure. Moreover, this protein plays a relevant role in shuttling proteins around the cell, fixing proteins at certain locations and, thus, enhancing stabilization of protein activity. RACK1 cooperates with the ribosomal machinery, with several cell surface receptors and with proteins in the nucleus. As a consequence, RACK1 constitutes a major mediator of various pathways, enhancing numerous phases of cellular function. RACK1 is a scaffolding protein that takes part in the maintenance of intestinal homeostasis protecting the integrity of the epithelial barrier by suppressing the regeneration and proliferation of crypt cells, promotes differentiation and apoptosis and is generated against stress responses [34-36]. Downregulation of both EBP1 and RACK1 may contribute to prevent the hyperplasia in the intestinal tissue that is associated with susceptibility to $E$. caproni infections.

Another striking feature that may be related with alterations in the intestinal epithelium and resistance to infections is the upregulation of annexins 2 and 4 in rIL-25-treated mice exposed to E. caproni metacercariae. Annexin is a common name for a family of structurally related proteins that mostly found in eukaryotic organisms both in extra and intracellular environment and bind phospholipids and carbohydrates in the presence 


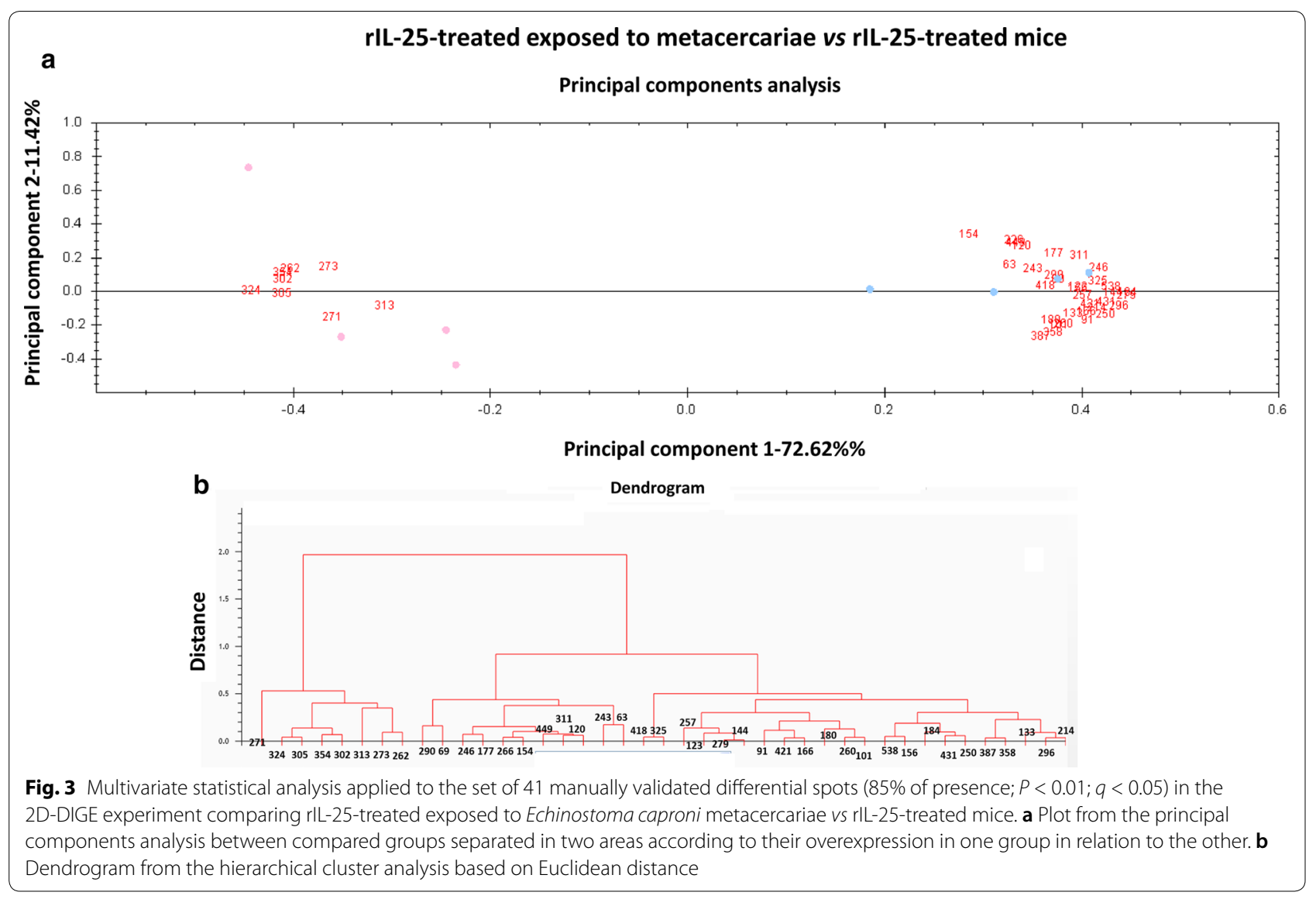

of $\mathrm{Ca}^{2+}[37,38]$. Annexins play a role in the control of cell death and also alters several properties of the membrane such as permeability or anchoring of cytoskeletal elements $[39,40]$. These proteins also are related to epithelial cell migration that is a critical event in gastrointestinal mucosal wound healing [41] Furthermore, annexins can act as modulators of inflammation [42]. In the small intestine, the production of annexins appears to be restricted to $M$ cells, playing a role in endocytic transport and membrane scaffolding [43]. Annexins are ligands for phosphatidylserine, which is exposed during cell death. Annexins block posphatidylserine-dependent phagocytosis of dying cells, enhancing its internalization and delivering phosphatidylserine back to the inner leaflet of the cell membrane [44]. Annexins are involved in the repair mechanisms both at tissue and intracellular levels [40]. Upregulation of annexins has been reported in association with resistance to $E$. caproni secondary infections in mice [38]. This was related to the decreased rate of cell death that occurs even though the induction of mitochondrial dysfunction, cellular senescence and elevated oxidative stress [38].

Specifically, annexin 4 appears to play a specific role in membrane repair. Plasma membrane repair mechanisms include internalization via endocitosis, or exocytosis as observed from mechanical wounding or exposure to plasma membrane pore-forming agents [45-48]. Therefore, overexpression of annexin 4 due to the exposure to metacercariae of rIL-25-treated mice may contribute to the defense against this parasite infection contributing to the restoration of the intestinal tissue and by its activity as an anti-inflammatory factor. Annexin 2 is a protein that is part of the lipid rafts in the intestinal brush border and is associated with actin filaments mediating in membrane-membrane and membrane-cytoskeletal interactions influencing actin cytoskeletal remodeling through targeting signaling molecules to membrane domains. As a consequence, it plays a crucial role in membrane trafficking and stabilization of membrane-associated protein complexes with the actin cytoskeleton and has been involved in the migration of several types of cells, such as epithelial cells and cell matrix interaction [41, 49-51]. Moreover, annexin 2 induces clustering of specific plasma membrane phospholipids and is involved in lipid domain formation [41]. The lack of annexin 2 would influence RhoA-mediated F-actin reorganization and, consequently, affecting motility of annexin 2 deficient cells [41]. In this sense, our results suggest that the 


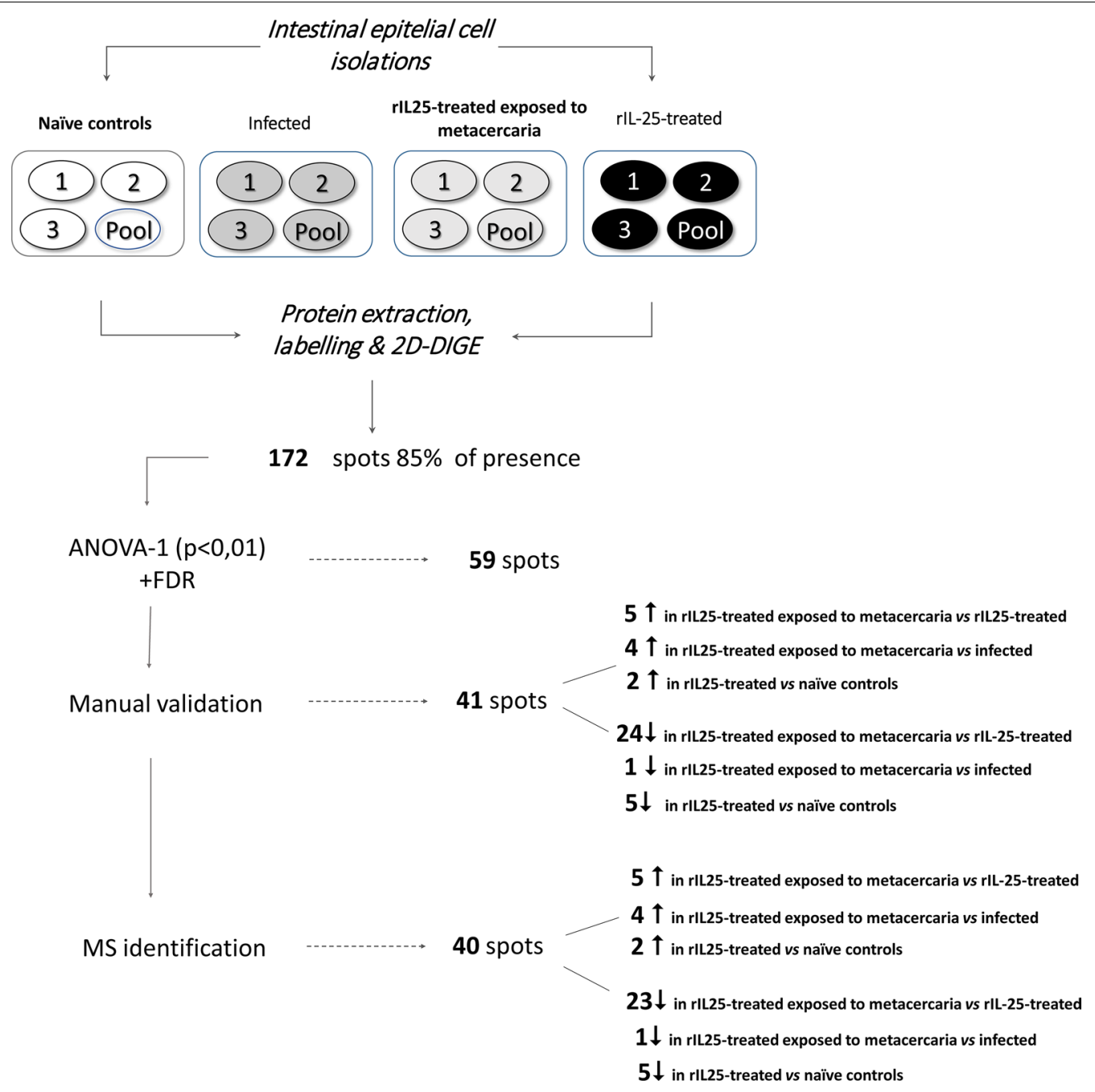

Fig. 4 Schematic overview of the results obtained by 2D-DIGE in the comparison of protein production profiles of intestinal epithelial cells isolated from naïve controls, rlL25-treated mice, infected animals and rlL25-treated mice exposed to metacercariae of Echinostoma caproni

upregulation of both annexins (annexin 2 and 4) could help maintain the epithelial barrier structure during helminth infections.

Quantitatively, the proteins involved in metabolic processes were the most altered in any of the groups studied. A total of 20 of the identified spots (corresponding to 15 different proteins) are metabolic enzymes and most of them were significantly downregulated in mice exposed to metacercariae in presence of rIL-25 with respect to rIL-25-treated mice. Alterations in several proteins implicated in the Krebs cycle (fumarate hydratase and malate dehydrogenase) and in the pentose phosphate pathway (transaldolase and 6-phosphogluconate dehydrogenase). We also observed a reduced expression of glycolytic enzymes including several isoforms of enolase $1 \mathrm{~B}$, glyceraldehyde-3-phosphate dehydrogenase and pyruvate kinase PKM, phosphoglycerate kinase
1 and triosephosphate isomerase. This may indicate a mitochondrial dysfunction and a reduction in aerobic metabolism after the exposure to E. caproni metacercariae. A similar situation has been described in the ileum of E. caproni mice at two weeks post-infection [20]. The decrease of aerobic metabolism was concomitant with a rise in the anaerobic use of glucose, through the overexpression of lactate dehydrogenase. However, Cortés et al. [38] detected a marked downregulation of the production of lactate dehydrogenase in the ileum of resistant secondarily infected mice, suggesting that both aerobic and anaerobic metabolism become impaired as the infection progresses. In contrast, in our study, lactate dehydrogenase was upregulated in the ileum of rIL25-treated mice exposed to the infection with respect to mice conventionally infected. This might indicate that infection requires an increase in the anaerobic use of 


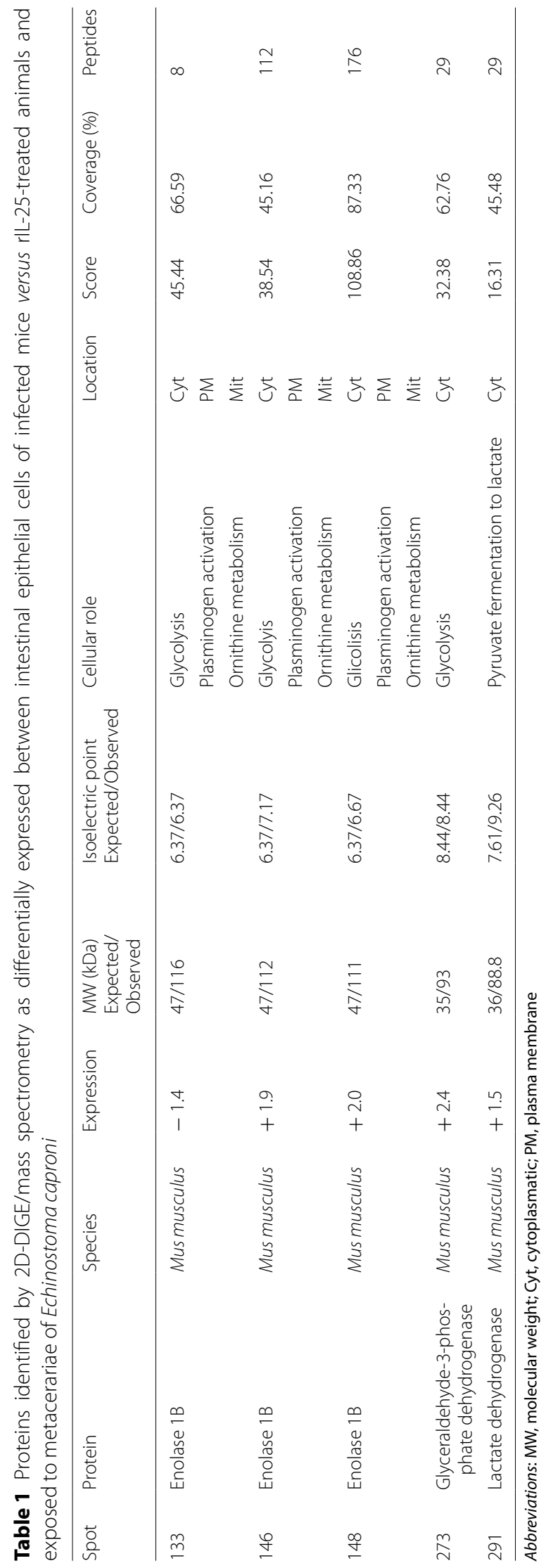




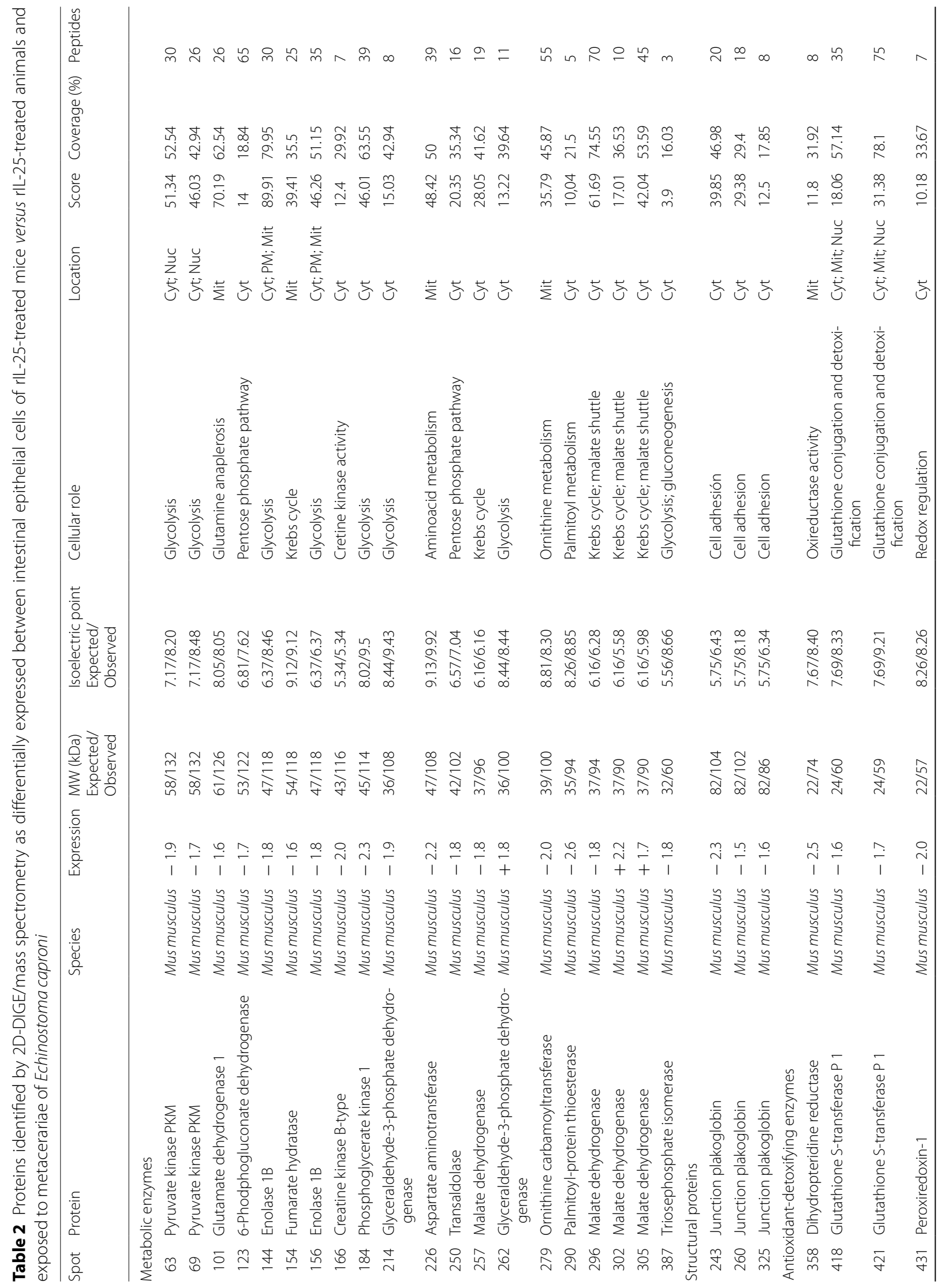




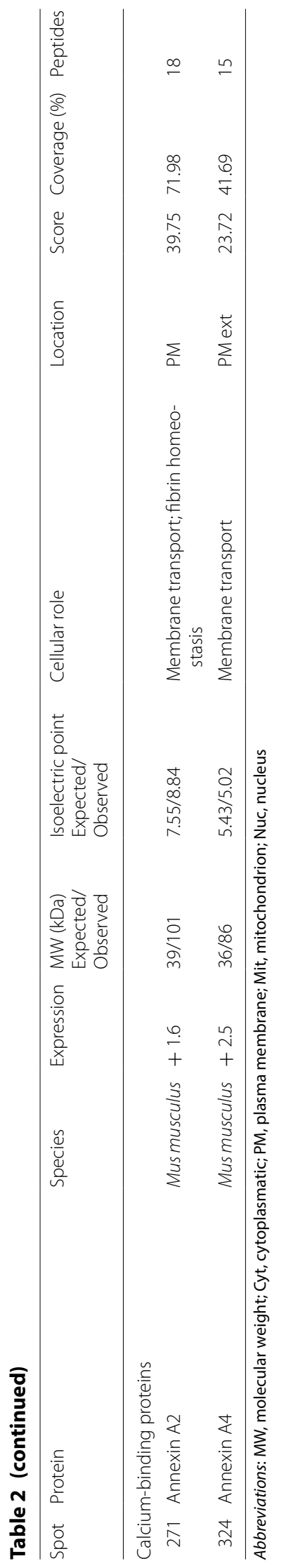




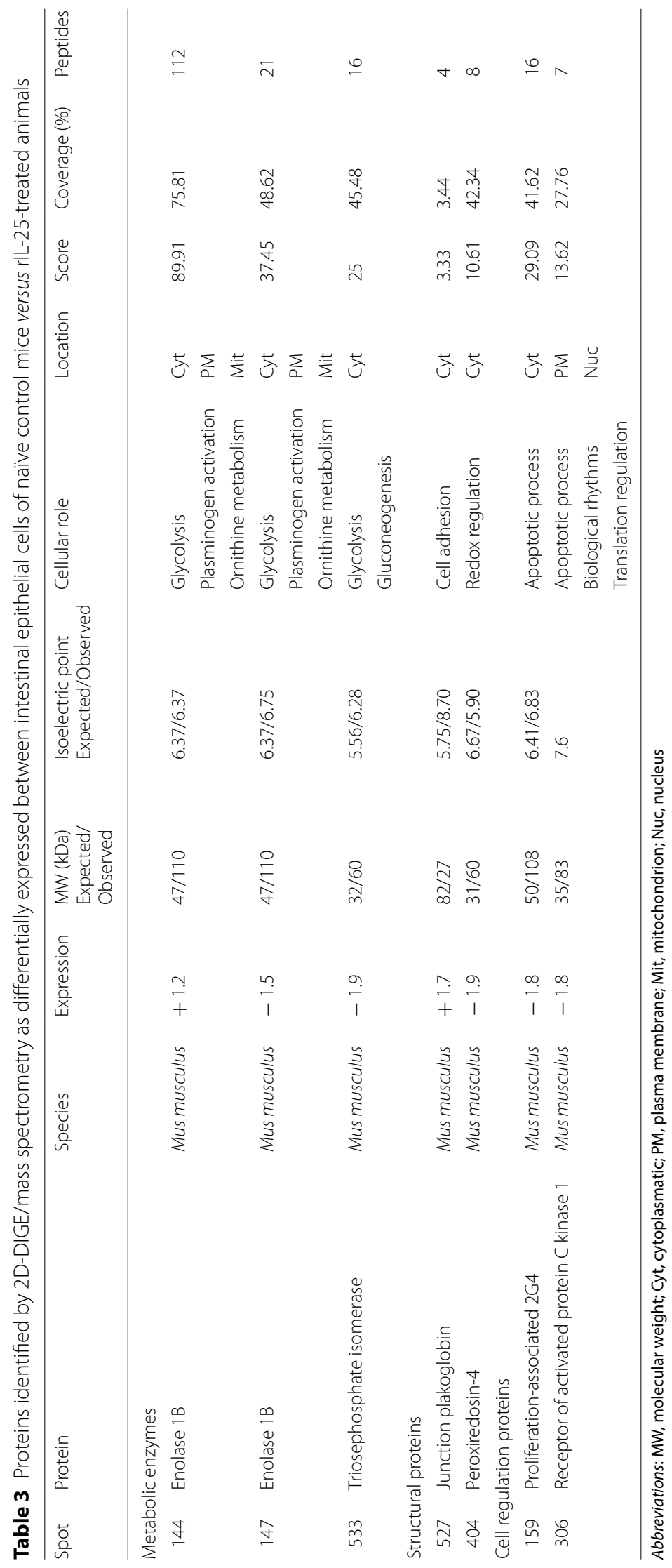


glucose to support the high energy demand caused by parasitic infection, both presence/absence of rIL-25 to cover the metabolic demand generated by mitochondrial dysfunction. The consequences of changes in the energy metabolism over the course of the infection is difficult to determine according to our current knowledge. However, it could be of importance to gain a better understanding of the mechanisms activated in the intestine as a consequence of helminth infections.

Several antioxidant and detoxifying enzymes such as peroxiredoxins 1 and 4, glutathione S-transferase and dihydropteridine reductase were also found to be altered. Treatment with rIL-25 induced a marked downregulation of peroxiredoxin 4. This enzyme is a ubiquitously expressed member of the peroxiredoxin family, localized in the endoplasmic reticulum and extracellular space [52]. Peroxiredoxin 4 has a role in the reduction of oxidative stress by diminishing hydrogen peroxide to water in a thioldependent catalytic cycle and has also been related to the regulation of nuclear factor kappa B (NF-kB), a key proinflammatory transcription factor [53-55]. This supports that the processes related to oxidative stress and cell death are altered in the presence of infection by $E$. caproni independently of the presence and IL-25. IL-25 does not appear to take part in the regulation of the processes related to oxidative stress and apoptosis necessary to maintain intestinal homeostasis. Strikingly, exposure of rIL-25-treated mice to metacercariae caused a downregulation of peroxiredoxin 1 instead of peroxiredoxin 4. Peroxiredoxin 1 plays a key role against reactive oxygen species and antioxidants and in inflammatory responses [56]. The production of this enzyme is upregulated in active ulcerative colitis specimens, and it increases along with the inflammation level in ulcerative colitis regenerative mucosal crypt epithelial cells $[57,58]$. Downregulation of peroxiredoxin 1 was observed as a consequence of the cure of an E. caproni infection [38]. The reduced production of this enzyme after infection in the presence of rIL-25 may promote crypt-cell proliferation and also induce oxidative stress and ROS-mediated programmed cell death to counteract homeostatic alterations induced by the infection $[20,59,60]$.

Infection of rIL-25-treated mice also induced reduction in the production of palmitoyl-protein thiosterase (PPT). Protein thioestherases, or depalmitoylases, participate the depalmitoylation of altered proteins, thus completing a cycle of this reversible post-translational modification [61-63]. Palmitoylation acts as a post-translational "switch" on several proteins providing dynamic control on protein localization or function. Indeed, palmitoylation plays critical roles in protein trafficking and strongly influences the stability of proteins [64-69]. PPT1 is a lysosomal substrate that enters into the lysosome via autophagy leading to signaling of several processes related with anabolic and catabolic metabolism in the cell $[63,70]$. PTT downregulation is implicated in the disruption of the lysosome-endosomal pathway and in other processes, such as endocytosis, vesicular trafficking, synaptic function, lipid metabolism, neural specification, and axon connectivity. Moreover, it appears to be implicated in susceptibility of cell to apoptotic death, defects in the mitochondrial enzyme activities and adaptive energy metabolism [71]. For this reason, downregulation of PPT after exposure to E. caproni metacercariae in the presence of rIL-25 in mice may be related to the role of this protein in processes of regulation of cell death and energy metabolism associated with the maintenance of the intestinal homeostasis. This is supported by the concomitant downregulation of creatine kinase B-type (CKB). This enzyme plays a critical role in energy transduction in tissues with increases in energy demands. The creatine kinase energy system is regulated by hypoxic signaling and can improve creatine metabolism during oxygen deficiency to enhance tissue healing and homeostasis [72]. Impaired $\mathrm{Cr} / \mathrm{PCr}$ shuttling may contribute to dysregulated mitochondrial energetics and an increased permeability characteristic of inflamed tissue and, consequently, susceptibility to E. caproni infection $[9,20,73]$.

\section{Conclusions}

Our results indicate that IL-25 and E. caproni infection in the presence of rIL-25 induce proteomic changes in the ileum of mice that may contribute to resistance to infection. The main groups of proteins that become altered were those involved in the preservation and healing of the epithelial architecture enhancing the maintenance of the epithelium. Considering our results overall, the maintenance of intestinal homeostasis seems to be essential for resistance to infection. Our study provides new insights into the proteins implicated in the regulation of tissue homeostasis in the presence of rIL-25, a cytokine that is considered as a target factor for the development of resistance to intestinal helminths.

\section{Supplementary information}

Supplementary information accompanies this paper at https://doi. org/10.1186/s13071-020-04206-y.

\footnotetext{
Additional file 1: Figure S1. Reference image of the 2D-DIGE gel in the experiment comparing infected mice $v$ s $\mathrm{rlL}$-25-treated animals, indicating the protein spots identified by mass spectrometry. Green squares indicate downregulated spots and red squares show upregulated spots. Identification details are shown in Table 1.

Additional file 2: Figure S2. Reference image of the 2D-DIGE gel in the experiment comparing infected $v s$ rlL-25-treated mice exposed to Echinostoma caproni metacercariae, indicating the protein spots identified by mass spectrometry. Green squares indicate downregulated spots and red squares show upregulated spots. Identification details are shown in Table 2.
} 
Additional file 3: Figure S3. Reference image of the 2D-DIGE gel in the experiment comparing rlL-25-treated exposed to Echinostoma caproni metacercariae vs rlL-25-treated mice, indicating the protein spots identified by mass spectrometry. Green squares indicate downregulated spots and red squares show upregulated spots. Identification details are shown in Table 3.

Additional file 4: Table S1. Details of the computational comparison of protein expression profiles of intestinal epithelial cells isolated from control, control inoculated with rlL-25, infected and infected in presence of rlL-25 mice performed with the EDA module of DeCyder software (GE Healthcare). Manually validated spots displaying significant statistical differences ( $P<0.01$ in one-way ANOVA) are pairwise comparisons of groups. Comparisons are based on the presence or absence of rlL-25, i.e. infected and control against infected in the presence of rIL25, and control inoculated with rlL-25 mice. For each spot in each pair, the fold-change and average normalised volumes (ANV) are shown.

\section{Abbreviations}

wpi: weeks post-infection; ppi: weeks post-primary infection; pzq: praziquantel; RELM- $\beta$ : resistin-like molecule beta; IEC: intestinal epithelial cells; HBSS: Hank's balanced salt solution; FCS: fetal calf serum; RT: room temperature; FDR: false discovery rate; PCA: unsupervised principal components analysis; HCA: hierarchical cluster analysis; GSK3 $\beta$ : glycogen synthase kinase; Wnt: the canonical wingless-related integrator site; SETD7: suppressor of variegation 3-9-Enhancer of zeste-Trithorax domain-containing family of lysine methyltransferases; RACK1: receptor of activated protein $C$ kinase 1; PA2G4: proliferation-associated 2G4; EBP1: proliferation-associated 2G4; GB: $\beta$ subunit of G-proteins.

\section{Acknowledgements}

The proteomic analysis was performed in the proteomics facility of SCSIE University of Valencia. This proteomics laboratory is a member of Proteored, PRB3 and is supported by grant PT17/0019, of the PE I+D+i 2013-2016, funded by ISCIII and ERDF.

\section{Authors' contributions}

MAl and RT carried out the experiments designed the experiments and wrote the manuscript. CMA and JGE analyzed the data and revised the manuscript. RT was the principal investigator for the project and was responsible for project design, statistical analysis, and writing the manuscript. All authors read and approved the final manuscript.

\section{Funding}

This work was supported by Ministerio de Economía y Competitividad (Madrid, Spain) (Grant Number: BFU2016-75639-P) and from Ministerio de Sanidad y Consumo (Madrid, Spain) (No. RD12/0018/0013, Red de Investigación Cooperativa en Enfermedades Tropicales - RICET, IV National Program of I+D+I 2008-2011, ISCIII - Subdirección General de Redes y Centros de Investigación Cooperativa and FEDER).

\section{Availability of data and materials}

The mass spectrometry proteomics data have been deposited to the ProteomeXchange Consortium via the PRIDE partner repository with the dataset identifier PXD019477.

\section{Ethics approval and consent to participate}

This study was approved by the Ethical Committee of Animal Welfare and Experimentation of the University of Valencia (Ref. \#A18348501775). Protocols adhered to Spanish (Real Decreto 53/2013) and European (2010/63/UE) regulations.

\section{Consent for publication \\ Not applicable.}

\section{Competing interests}

The authors declare that they have no competing interests.
Received: 6 April 2020 Accepted: 24 June 2020

Published online: 02 July 2020

\section{References}

1. Gazzinelli-Guimaraes PH, Nutman TB. Helminth parasites and immune regulation. F1000Res. 2018;7:1685.

2. Nokes C, Bundy DA. Does helminth infection affect mental processing and educational achievement? Parasitol Today. 1994;10:14-8.

3. Bethony J, Brooker S, Albonico M, Geiger SM, Loukas A, Diemert D, et al. Soil-transmitted helminth infections: ascariasis, trichuriasis, and hookworm. Lancet. 2006:367:1521-32.

4. Hotez PJ, Alvarado M, Basáñez MG, Bolliger I, Bourne R, Boussinesq M, et al. The global burden of disease study 2010: interpretation and implications for the neglected tropical diseases. PLoS Negl Trop Dis. 2014;8:e2865.

5. Toledo R, Alvárez-Izquierdo M, Muñoz-Antoli C, Esteban JG. Intestinal trematode infections. Adv Exp Med Biol. 2019;1154:181-213.

6. Fürst T, Keiser J, Utzinger J. Global burden of human food-borne trematodiasis: a systematic review and meta-analysis. Lancet Infect Dis. 2012;12:210-21.

7. Toledo R, Esteban JG, Fried B. Recent advances in the biology of echinostomes. Adv Parasitol. 2009:69:147-204.

8. Toledo R, Espert A, Carpena I, Muñoz-Antoli C, Fried B, Esteban JG. The comparative development of Echinostoma caproni (Trematoda: Echinostomatidae) adults in experimentally infected hamsters and rats. Parasitol Res. 2004;93:439-44.

9. Muñoz-Antoli C, Sotillo J, Monteagudo C, Fried B, Marcilla A, Toledo R. Development and pathology of Echinostoma caproni in experimentally infected mice. J Parasitol. 2007:93:854-89.

10. Owyang AM, Zaph C, Wilson EH, Guild KJ, McClanahan T, Miller HR, et al. Interleukin 25 regulates type 2 cytokine-dependent immunity and limits chronic inflammation in the gastrointestinal tract. J Exp Med. 2006:203:843-9.

11. Kleinschek MA, Owyang AM, Joyce-Shaikh B, Langrish CL, Chen Y, Gorman DM, et al. IL-25 regulates Th17 function in autoimmune inflammation. J Exp Med. 2007;204:161-70.

12. Liu DL, Zhao LX, Zhang S, Du JR. Peroxiredoxin 1-mediated activation of TLR4/NF-KB pathway contributes to neuroinflammatory injury in intracerebral hemorrhage. Int Immunopharmacol. 2016;41:82-9.

13. Cortés A, Muñoz-Antoli C, Esteban JG, Toledo R. Th2 and Th1 responses: clear and hidden sides of immunity against intestinal helminths. Trends Parasitol. 2017;33:678-93.

14. Muñoz-Antoli C, Cortés A, Martin-Grau C, Fried B, Esteban JG, Toledo R. Partial resistance to homologous challenge infections of the digenean Echinostoma caproni in ICR mice. J Helminthol. 2016;90:428-33.

15. Muñoz-Antoli C, Cortés A, Santano R, Sotillo J, Esteban JG, Toledo R. Interleukin-25 induces resistance against intestinal trematodes. Sci Rep. 2016;6:34142.

16. Fujino T, Fried B. Echinostoma caproni and E. trivolvis alter the binding of glycoconjugates in the intestinal mucosa of $\mathrm{C} 3 \mathrm{H}$ mice as determined by lectin histochemistry. J Helminthol. 1993;67:179-88.

17. Muñoz-Antoli C, Cortés A, Sotillo J, Fried B, Esteban JG, Toledo R. Differential expression and glycosylation of proteins in the rat ileal epithelium in response to Echinostoma caproni infection. J Proteomics. 2014;101:169-78

18. Silva TS, Richard N, Dias JP, Rodrigues PM. Data visualization and feature selection methods in gel-based proteomics. Curr Protein Pept Sci. 2014;15:4-22.

19. Cortés A, Muñoz-Antoli C, Sotillo J, Fried B, Esteban JG, Toledo R. Echinostoma caproni (Trematoda): differential in vivo mucin expression and glycosylation in high- and low-compatible hosts. Parasite Immunol. 2015;37:32-42.

20. Cortés A, Sotillo J, Muñoz-Antoli C, Fried B, Esteban JG, Toledo R. Altered protein expression in the ileum of mice associated with the development of chronic infections with Echinostoma caproni (Trematoda). PLoS Negl Trop Dis. 2015:9:e0004082.

21. Shevchenko A, Tomas H, Havlis J, Olsen JV, Mann M. In-gel digestion for mass spectrometric characterization of proteins and proteomes. Nat Protoc. 2006;1:2856-60. 
22. Yin T, Getsios S, Caldelari R, Kowalczyk AP, Müller EJ, Jones JC, et al. Plakoglobin suppresses keratinocyte motility through both cell-cell adhesion-dependent and -independent mechanisms. Proc Natl Acad Sci USA. 2005;102:5420-5.

23. Aktary Z, Bertrand JU, Larue L. The WNT-less wonder: WNT-independent $\beta$-catenin signaling. Pigment Cell Melanoma Res. 2016;29:524-40.

24. Fevr T, Robine S, Louvard D, Huelsken J. Wnt/beta-catenin is essential for intestinal homeostasis and maintenance of intestinal stem cells. Mol Cell Biol. 2007:27:7551-9.

25. Morgan RG, Pearn L, Liddiard K, Pumford SL, Burnett AK, Tonks A, et al. $\gamma$-catenin is overexpressed in acute myeloid leukemia and promotes the stabilization and nuclear localization of $\beta$-catenin. Leukemia. 2013;F27:336-43

26. Qian J, Huang X, Zhang Y, Ye X, Qian W. Y-catenin overexpression in AML patients may promote tumor cell survival via activation of the $\mathrm{Wnt} / \beta$ catenin axis. Onco Targets Ther. 2020;13:1265-76.

27. Ackers I, Malgor R. Interrelationship of canonical and non-canonical Wnt signalling pathways in chronic metabolic diseases. Diab Vasc Dis Res. 2018;15:3-13.

28. Jacobs KM, Bhave SR, Ferraro DJ, Jaboin JJ, Hallahan DE, Thotala D. GSK-3ß: a bifunctional role in cell death pathways. Int J Cell Biol. 2012;2012:930710.

29. Oudhoff MJ, Antignano F, Chenery AL, Burrows K, Redpath SA, Braam $\mathrm{MJ}$, et al. Intestinal epithelial cell-intrinsic deletion of Setd7 identifies role for developmental pathways in immunity to helminth infection. PLoS Pathog. 2016;12:e1005876.

30. Zhang Y, Hamburger AW. Heregulin regulates the ability of the ErbB3binding protein Ebp1 to bind E2F promoter elements and repress E2Fmediated transcription. J Biol Chem. 2004;279:26126-33.

31. Karlsson T, Altankhuyag A, Dobrovolska O, Turcu DC, Lewis AE. A polybasic motif in ErbB3-binding protein 1 (EBP1) has key functions in nucleolar localization and polyphosphoinositide interaction. Biochem J. 2016:473:2033-47.

32. Zhang Y, Lu Y, Zhou H, Lee M, Liu Z, Hassel BA, Hamburger AW. Alterations in cell growth and signaling in ErbB3 binding protein-1 (Ebp1) deficient mice. BMC Cell Biol. 2008;9:69.

33. Lyne JC, Melhem MF, Finley GG, Wen D, Liu N, Deng DH, et al. Tissue expression of neu differentiation factor/heregulin and its receptor complex in prostate cancer and its biologic effects on prostate cancer cells in vitro. Cancer J Sci Am. 1997;3:21-30.

34. Mamidipudi V, Cartwright CA. A novel pro-apoptotic function of RACK1: suppression of Src activity in the intrinsic and Akt pathways. Oncogene. 2009;28:4421-33.

35. Adams DR, Ron D, Kiely PA. RACK1, a multifaceted scaffolding protein: structure and function. Cell Commun Signal. 2011;9:22.

36. Duff D, Long A. Roles for RACK1 in cancer cell migration and invasion. Cell Signal. 2017:35:250-5.

37. Monastyrskaya K, Babiychuk EB, Draeger A. The annexins: spatial and temporal coordination of signaling events during cellular stress. Cell Mol Life Sci. 2009;66:2623-42.

38. Cortés A, Sotillo J, Muñoz-Antolí C, Martín-Grau C, Esteban JG, Toledo R. Resistance against Echinostoma caproni (Trematoda) secondary infections in mice is not dependent on the ileal protein production. J Proteomics. 2016;140:37-47

39. Gerke V, Creutz CE, Moss SE. Annexins: linking Ca2+ signalling to membrane dynamics. Nat Rev Mol Cell Biol. 2005;6:449-61.

40. Gerke V, Moss SE. Annexins: from structure to function. Physiol Rev. 2002:82:331-71.

41. Babbin BA, Parkos CA, Mandell KJ, Winfree LM, Laur O, Ivanov Al, et al. Annexin 2 regulates intestinal epithelial cell spreading and wound closure through Rho-related signaling. Am J Pathol. 2007;170:951-66.

42. Wallner BP, Mattaliano RJ, Hession C, Cate RL, Tizard R, Sinclair LK, et al. Cloning and expression of human lipocortin, a phospholipase A2 inhibitor with potential anti-inflammatory activity. Nature. 1986;320:77-81.

43. Verbrugghe P, Waelput W, Dieriks B, Waeytens A, Vandesompele J, Cuvelier CA. Murine M cells express annexin V specifically. J Pathol. 2006;209:240-9

44. Kenis $\mathrm{H}$, van Genderen H, Deckers NM, Lux PA, Hofstra L, Narula J, et al. Annexin A5 inhibits engulfment through internalization of PS-expressing cell membrane patches. Exp Cell Res. 2006;312:719-26.
45. Steinhardt RA, Bi G, Alderton JM. Cell membrane resealing by a vesicular mechanism similar to neurotransmitter release. Science. 1994;263:390-3.

46. Idone V, Tam C, Goss JW, Toomre D, Pypaert M, Andrews NW. Repair of injured plasma membrane by rapid $\mathrm{Ca}^{2+}$-dependent endocytosis. J Cell Biol. 2008;180:905-14

47. Corrotte M, Almeida PE, Tam C, Castro-Gomes T, Fernandes MC, Millis BA, et al. Caveolae internalization repairs wounded cells and muscle fibers. Life. 2013;2:e00926.

48. Boye TL, Maeda K, Pezeshkian W, Sønder SL, Haeger SC, Gerke V, et al. Annexin A4 and A6 induce membrane curvature and constriction during cell membrane repair. Nat Commun. 2017:8:1623.

49. Merrifield CJ, Rescher U, Almers W, Proust J, Gerke V, Sechi AS, et al. Annexin 2 has an essential role in actin-based macropinocytic rocketing. Curr Biol. 2001;11:1136-41.

50. Grill D, Matos ALL, de Vries WC, Kudruk S, Heflik M, Dörner W, et al. Bridging of membrane surfaces by annexin A2. Sci Rep. 2018:8:14662.

51. Desrosiers RR, Gauthier F, Lanthier J, Béliveau R. Modulation of Rho and cytoskeletal protein attachment to membranes by a prenylcysteine analog. J Biol Chem. 2000;275:14949-57.

52. Tavender TJ, Springate JJ, Bulleid NJ. Recycling of peroxiredoxin IV provides a novel pathway for disulphide formation in the endoplasmic reticulum. EMBO J. 2010;29:4185-97.

53. Wood ZA, Poole LB, Karplus PA. Peroxiredoxin evolution and the regulation of hydrogen peroxide signalling. Science. 2003;300:650-3.

54. Yu S, Mu Y, Ao J, Chen X. Peroxiredoxin IV regulates pro-inflammatory responses in large yellow croaker (Pseudosciaena crocea) and protects against bacterial challenge. J Proteome Res. 2010;9:1424-36.

55. Yanagisawa R, Warabi E, Inoue K, Yanagawa T, Koike E, Ichinose T, et al. Peroxiredoxin I null mice exhibits reduced acute lung inflammation following ozone exposure. J Biochem. 2012;152:595-601.

56. Liu CH, Kuo SW, Hsu LM, Huang SC, Wang CH, Tsai PR, et al. Peroxiredoxin 1 induces inflammatory cytokine response and predicts outcome of cardiogenic shock patients necessitating extracorporeal membrane oxygenation: an observational cohort study and translational approach. J Transl Med. 2016;14:114.

57. Waage A, Brandtzaeg P, Halstensen A, Kierulf P, EspevikT. The complex pattern of cytokines in serum from patients with meningococcal septic shock. Association between interleukin 6, interleukin 1, and fatal outcome. J Exp Med. 1989;169:333-8.

58. Zhao Y, Oberley TD, Chaiswing L, Lin SM, Epstein CJ, Huang TT, et al. Manganese superoxide dismutase deficiency enhances cell turnover via tumour promoter-induced alterations in AP-1 and p53-mediated pathways in a skin cancer model. Oncogene. 2002;21:3836-46.

59. Hu W, Chen SS, Zhang JL, Lou XE, Zhou HJ. Dihydroartemisinin induces autophagy by suppressing NF-kB activation. Cancer Lett. 2014:343:239-48

60. Mizushima N. Autophagy: process and function. Genes Dev. 2007:21:2861-73.

61. Mizushima N, Komatsu M. Autophagy: renovation of cells and tissues. Cell. 2011;147:728-41

62. Koster KP, Yoshii A. Depalmitoylation by palmitoyl-protein thioesterase 1 in neuronal health and degeneration. Front Synaptic Neurosci. 2019;11:25.

63. Dunphy J, Linder M. Signaling functions of protein palmitoylation. Biochim Biophys Acta. 1998;1436:245-61.

64. Linder ME, Deschenes RJ. Palmitoylation: policing protein stability and traffic. Mol Cell Biol. 2007:8:74-84.

65. Fukata Y, Fukata M. Protein palmitoylation in neuronal development and synaptic plasticity. Nat Rev Neurosci. 2010;11:161-75.

66. Salaun C, Greaves J, Chamberlain L. The intracellular dynamic of protein palmitoylation. J Cell Biol. 2010;191:1229-38.

67. Chamberlain LH, Lemonidis K, Sanchez-Perez M, Werno MW, Gorleku OA, Greaves J. Palmitoylation and the trafficking of peripheral membrane proteins. Biochem Soc Trans. 2013:41:62-6.

68. Montersino A, Thomas GM. Slippery signaling: palmitoylation-dependent control of neuronal kinase localization and activity. Mol Membr Biol. 2015;32:179-88.

69. Perera RM, Zoncu R. The lysosome as a regulatory hub. Annu Rev Cell Dev Biol. 2016;32:223-53. 
70. Kang R, Wan J, Arstikaitis P, Takahashi H, Huang K, Bailey AO, et al. Neural palmitoyl-proteomics reveals dynamic synaptic palmitoylation. Nature. 2008;2008(456):904-9.

71. Glykys J, Sims KB. The neuronal ceroid lipofuscinosis disorders. In: Swaiman KF, Ferreiro DM, Finkel RS, Pearl PL, Ashwal S, Schor NF, Gropman $A L$, Shevell MZ, editors. Swaiman's pediatric neurology. 6th ed. Amsterdam: Elsevier; 2017. p. 390-404.

72. Mooseker MS. Organization, chemistry, and assembly of the cytoskeletal apparatus of the intestinal brush border. Annu Rev Cell Biol. 1985;1:209-41.
73. Toledo R, Monteagudo C, Espert A, Fried B, Esteban JG, Marcilla A. Echinostoma caproni: intestinal pathology in the golden hamster, a highly compatible host, and the Wistar rat, a less compatible host. Exp Parasitol. 2006;112:164-71

\section{Publisher's Note}

Springer Nature remains neutral with regard to jurisdictional claims in published maps and institutional affiliations.
Ready to submit your research? Choose BMC and benefit from:

- fast, convenient online submission

- thorough peer review by experienced researchers in your field

- rapid publication on acceptance

- support for research data, including large and complex data types

- gold Open Access which fosters wider collaboration and increased citations

- maximum visibility for your research: over 100M website views per year

At BMC, research is always in progress.

Learn more biomedcentral.com/submissions 